\title{
ANALISIS PENDAPATAN USAHATANI BAWANG MERAH DI DESA TONSEWER SELATAN KECAMATAN TOMPASO BARAT KABUPATEN MINAHASA
}

\author{
Katika Enda Ia \\ Caronline B. D. Pakasi \\ Lorraine W. Th. Sondak
}

\begin{abstract}
This study aims to analyze the income of red onion farming in Tonsewer Village, West Tompaso Sub-district, Minahasa Regency. The data used are primary and secondary data. Primary data was obtained through prepared statement list while secondary data was obtained from BP3K West Tompaso Sub-district (Central Bureau of Statistics), internet and previous research. This research was conducted in South Tonsewer Village, West Tompaso Sub-district, which is a production center of red onion. Sample research method is done by purposive sampling (purposely), where the sample is obtained based on information from the respondents who have been interviewed. Data is presented in numerical and quantitative form. Variable measurement concept used is selling price and production costs. The results of this study indicate that the people of South Tonsewer Village rely on the field of agriculture especially the red onion, because it has a bright prospect in the sense worth to be cultivated (profitable). This can be indicated from the $R / C$ ratio. Revenue Cost Ratio $(R / C)$ is 1.77 of the calculation of revenue divided by total cost. This means that every Rp.1.00 cost incurred will get revenue amounting to Rp.1.77 Criteria $R / C>1=$ the farmers of farmers on the farmers of red onion on the South Tonsewer beneficial.*1wths*.
\end{abstract}

Keywords: income analysis, red onion farming, South Tonsewer Village,

West Tompaso Sub-district, Minahasa Regency.

\begin{abstract}
ABSTRAK
Penelitian ini bertujuan untuk menganalisis pendapatan usahatani bawang merah di Desa Tonsewer Kecamatan Tompaso Barat Kabupaten Minahasa. Data yang digunakan yaitu data primer dan sekunder. Data primer diperoleh melalui daftar pernyataan yang telah disiapkan sedangkan data sekunder diperoleh dari BP3K Kecamatan Tompaso Barat (Badan Pusat Statisika), internet dan penelitian terdahulu. Penelitian ini dilakukan di Desa Tonsewer Selatan Kecamatan Tompaso Barat yang merupakan sentra produksi bawang merah. Metode penelitian sampel dilakukan dengan cara purposive sampling (sengaja), dimana sampel diperoleh berdasarkan informasi dari responden yang telah diwawancarai. Data disajikan dalam bentuk angka dan analisi secara kuantitatif. Konsep pengukuran Variabel yang digunakan adalah harga jual dan biaya- biaya produksi. Hasil penelitian ini menunjukkan bahwa masyarakat Desa Tonsewer Selatan mengandalkan bidang pertanian khususnya bawang merah, karena mempunyai prospek yang cerah dalam arti layak untuk diusahakan (menguntungkan). Hal ini dapat di tunjukkan dari nilai R/C ratio. Revenue Cost Ratio (R/C) adalah 1,77 dari perhitungan penerimaan dibagi dengan total biaya. Artinya bahwa setiap Rp.1,00 biaya yang dikeluarkan maka akan mendapatkan penerimaan sebesar Rp.1.77 Kriteria R/C >1= maka usahatani responden petani Bawang Merah di Desa Tonsewer Selatan menguntungkan. *lwths*.
\end{abstract}

Kata kunci: analisis pendapatan, usahatani bawang merah, Desa Tonsewer Selatan,

Kecamatan Tompaso Barat, Kabupaten Minahasa. 


\section{PENDAHULUAN}

\section{Latar Belakang}

Pembangunan sektor pertanian memegang peranan penting dalam usahatani meningkatkan kegiatan ekonomi Indonesia, hal ini ditunjukkan dari penduduknya yang masih dominan bekerja di sektor pertanian memegang peranan penting dari keseluruhan perekonomian nasional yang Kondisi tersebut mengarahkan tujuan pembangunan nasional pada sektor pertanian yaitu untuk meningkatkan produksi pertanian dalam rangka memenuhi konsumsi dalam negeri dan untuk ekspor disamping itu untuk memanfaatkan sumber daya alam yang tersedia dan tetap menjaga kelestariannya.

Sektor pertanian Indonesia terdiri dari tiga subsektor yaitu subsektor tanaman perkebunan, tanaman pangan dan tanaman hortikultura. Hortikultura sebagai salah satu subsektor petanian terdiri dari berbagai jenis tanaman, yaitu tanaman buah-buahan, tanaman sayuran, tanaman biofarmaka, dan tanaman hias.

Menurut studi penawaran dan permintaan komoditas hortikultura, paling sedikit mempunyai tiga peran penting terhadap perekonomian Indonesia, yaitu: (1) sumber pendapatan masyarakat; (2) bahan pangan masyarakat khususnya sumber vitamin (buahbuahan), mineral (sayuran) dan bumbu masak dalam memenuhi kebutuhan gizi masyarakat; dan (3) sumber devisa Negara non-migas (PPSEP Deptan 2001)

Tahun 2015 Indonesia mengekspor bawang merah kebeberapa negara seperti: Thailand, Singapura, Malaysia, Vietnam, Taiwan, Timor Leste, Jepang, Uni Emirat Arab, Pulau Natal, Hongkong, Republik Rakyat Cina, Qatar, Papua Nugini, Indonesia mengekspor bawang merah ke beberapa negara tersebut sebanyak 8.418.274 Kg (BPS Indonesia 2015).

Pendapatan yang cukup besar dalam ekonomi pertanian tidak bermakna bila harus didapatkan dengan menggunakan pencurahan biaya produksi dengan jumlah besar pula. Namun sebenarnya pilihan-pilihan yang paling penting dilakukan petani adalah bagaimana memperoleh rasio yang cukup besar antara pendapatan yang diperoleh dari kegiatan usahataninya bila dibandingkan dengan total biaya produksi yang telah dikeluarkan. Semakin besar rasio yang diperoleh maka semakin tepat pilihan-pilhan penggunaan sumberdaya yang dilakukan untuk kegiatan usahataninya (Soekartawi, 1985).

Pada tahun 2015 Sulawesi utara adalah salah satu provpinsi yang memproduksi komoditi bawang merah dengan luas panen sebesar 310 ha, produksi sebesar 17155 ton dan rata - rata produksi sebesar 55.34 ton/ha (BPS Sulut 2017). Di Kabupaten Minahasa ada beberapa desa yang baik untuk pertumbuhan tanaman bawang merah, salah satunya di desa tonsewer selatan Kecamatan Tompaso Barat desa Tonsewer Selatan merupakan salah satu sentra produksi bawang merah di Sulawesi utara dilihat dari data luas tanam, luas panen dan jumlah produksi. Berikut ini tabel yang menunjukkan luas tanam, luas panen dan produksi bawang merah di Kecamatan Tompaso Barat.

Tabel 1 Luas Tanam, Luas Panen, Rata-Rata Produksi dan Produksi Bawang Merah di Kecamatan Tompaso Barat Tahun 2015

\begin{tabular}{lcccc}
\hline Desa & $\begin{array}{c}\text { Luas } \\
\text { Tanam } \\
\text { (Ha) }\end{array}$ & $\begin{array}{c}\text { Luas } \\
\text { Panen } \\
\text { (Ha) }\end{array}$ & $\begin{array}{c}\text { Produksi } \\
\text { (Ton) }\end{array}$ & $\begin{array}{c}\text { Rata-rata } \\
\text { Produksi } \\
\text { (Ton/Ha) }\end{array}$ \\
\hline Pinaesaan & 0,5 & 0,5 & 3,05 & 6,1 \\
Tompaso II & 5 & 5 & 31 & 6,2 \\
Tompaso II Utara & - & - & - & - \\
Pinabetengan & 2,5 & 2,5 & 15,75 & 6,3 \\
Pinabetengan Utara & 3 & 3 & 18,3 & 6,1 \\
Pinabetengan Selatan & 4 & 4 & 25,2 & 6,3 \\
Tonsewer & 35 & 35 & 280 & 8.0 \\
Touure & 7,5 & 7,5 & 48 & 6,8 \\
Tonsewer Selatan & 33 & 33 & 264 & 8,0 \\
Touree II & 5 & 5 & 32 & 6,8 \\
\hline Sumber : BP3K Kecamatan Tompaso Barat, 2016
\end{tabular}

Tabel 1 Menunjukkan bahwa desa Tonsewer Selatan sebagai sentra produksi bawang merah tertinggi kedua di kecamatan Tompaso Barat yang mempunyai jumlah produksi 264 ton pertahun dengan produktivitas sebesar 8 ton perhektar. walaupun produksi bawang merah cukup tinggi belum menjamin terjadinya peningkatan pendapatan petani, sebab banyak factor yang mempengaruhinya.

Tahun 2016 Kecamatan Tompaso Barat memproduksi bawang merah tertinggi sebesar 863 ton dengan luas panen sebesar 102 ha. pada Kecamatan tersebut terdapat beberapa desa yang merupakan sentra produksi bawang merah. salah satunya adalah Desa Tonsewer Selatan 
umumnya penduduk Desa Tonsewer Selatan adalah sebagai petani sedangkan lainnya adalah pegawai, pensiunan dan peternak.

Menurut Dondokambey (2017), Tompaso Barat sebagai sentra produksi bawang merah telah memiliki varietas unggul "Lansuna" yang telah bersertifikat dan memiliki SK dari kementerian pertanian. Ciri khas bawang merah varietas lansuna yaitu memiliki ukuran yang lebih besar dari ukuran bawang merah rata-rata yang beredar dipasaran dan bisa ditanam kapan saja tanpa mengenal musim. Berdasarkan survey awal pada lima tahun belakangan ini bawang merah khas Tonsewer Selatan telah menjadi icon pada setiap pameran di daerah maupun di Provinsi Sulut bahkan juga sudah diperkenal hingga ke luar kota seperti ikut Penas di Malang.

Usahatani bawang merah mampu mendatangkan keuntungan yang jauh lebih besar jika dibandingkan dengan usahatani pada komoditas pangan seperti padi atau jagung. Menurut Dinas Pertanian yang dikutip dalam Natawidjaja (2007) Secara teoritis, tingkat pendapatan masyarakat dalam kesatuan wilayah perekonomian pasti tidak sama jumlahnya, hal mana disebabkan oleh adanya perbedaan keahlian dan pendidikan, jenis pekerjaan, tingkat upah dan lain sebagainya.

\section{Rumusan Masalah}

Bagaimana pendapatan usahatani bawang merah di Desa Tonsewer Selatan Kecamatan Tompaso Barat Kabupaten Minahasa.

\section{Tujuan Penelitian}

Untuk menganalisis pendapatan usahatani bawang merah di Desa Tonsewer Kecamatan Tompaso Barat Kabupaten Minahasa.

\section{Manfaat Penelitian}

Dapat memberikan informasi bagi pihakpihak yang memerlukannya untuk menambah wawasan dan pengetahuan yang lebih luas tingkat pendapatan usahatani bawang merah serta dapat digunakan sebagai bahan kajian untuk peningkatan usahatani dalam rangka mencapai keuntungan yang maksimal.

\section{METODE PENELITIAN}

\section{Waktu dan Tempat Penelitian}

Penelitian ini dilakukan selama dua bulan mulai dari tahap persiapan hingga penyusunan laporan yakni mulai bulan Febuari sampai bulan Juni Tahun 2018. Lokasi penelitian dilaksanakan di Desa Tonsewer Selatan.

\section{Metode Pengumpulan Data}

Data yang dikumpulkan dalam penelitian ini terdiri atas dua jenis yaitu:

1. Data Primer, diperoleh melalui wawancara langsung dengan menggunakan kuisioner yang berisikan pertanyaan-pertanyaan secara tertulis pada responden untuk mendapatkan jawaban, tanggapan dan informasi yang diperlukan oleh peneliti.

2. Data Sekunder, diperoleh melalui pencatatan pada instansi atau lembaga terkait dengan penelitian ini serta literatur yang menunjang dan memiliki hubungan dengan penelitian ini.

\section{Teknik Pengambilan Sampel}

Pengambilan sampel secara proposive sampling (sengaja) Responden yang diambil adalah petani bawang merah lansuna sebanyak 30 petani berdasarkan luas pemilik lahan sendiri.

\section{Konsep Pengukuran Variabel}

1. Tingkat produksi adalah besarnya jumlah yang dihasilkan petani dalam sekali masa tanam yang di hitung dalam $\mathrm{Kg}$.

2. Biaya produksi semua biaya yang dikeluarkan oleh petani untuk mengelolah bawang merah yang dihitung dalam satuan Rp yang terdiri dari :

a. Pembelian benih / bibit, pupuk

b. Modal

c. Pembelian Peralatan

d. Biaya Tenaga kerja

e. Pajak / iuran yaitu pajak yang dikenakan pada lahan dihitung dalam $\mathrm{Rp} /$ Tahun

f. Luas lahan

g. Pengaruh umur petani

3. $\mathrm{R} / \mathrm{C}$ ratio adalah ratio imbangan antara biaya dengan penerimaan yang dihasilkan 
dimana R/C Menunjukkan besarnya penerimaan yang diperoleh dari setiap rupiah yang dikeluarkan.

\section{Analisis Data}

Analisis data yang digunakan adalah metode analisis kuantitatif. analisis kuantitatif bertujuan untuk menganalisis pendapatan usahatani bawang merah untuk mengetahui apakah dalam pendapatan usahtani bawang merah menguntungkan atau tidak data yang dikumpulkan dalam penelitian ini kemudian dianalisis dengan menggunakan analisis pendapatan yaitu dengan menghitung selisih antara penerimaan dengan biaya yang digunakan. data yang dikumpulkan akan disajikan dalam bentuk variabel dan deskriptif.

Kemudian dilanjutkan dengan rumus Analisis Revenue Cost Ratio (R/C). Untuk mengukur keuntungan digunakan rumus sebagai berikut:

Dimana:

$$
\pi=\mathrm{TR}-\mathrm{TC}
$$

$\pi=$ Profit (pendapatan)

$\mathrm{TR}=$ Total Revenue (Total Penerimaan)

$\mathrm{TC}=$ Total Cost $($ Total Biaya $)$

Dimana:

$$
\mathrm{TR}=\mathrm{Q} \times \mathrm{P}
$$

TR $=$ Total Penerimaan

$\mathrm{Q}=$ Jumlah Produksi

$\mathrm{P}=$ Harga

Dimana:

$$
\mathrm{TC}=\mathrm{FC}+\mathrm{VC}
$$

$\mathrm{TC}($ Total Revenue $)=$ Total Biaya

FC $($ Fixed Cost $)=$ Biaya Tetap

VC $($ Variabel Cost $)=$ Biaya Variabel

Kemudian untuk mengetahui apakah ushatani bawang merah ini menguntungkan atau tidak dapat digunakan dengan rumus:

$$
a=R / C
$$

Apabila:

$$
\begin{aligned}
\mathrm{R} / \mathrm{C}<1= & \text { Berarti Usaha bawang merah tidak } \\
& \text { mengalami keuntungan (tidak dapat } \\
& \text { diteruskan) }
\end{aligned}
$$

$\mathrm{R} / \mathrm{C}=1=$ Berarti Usahatani bawang merah ini berada pada titik stabil

$\mathrm{R} / \mathrm{C}>1=$ Berarti Usaha bawang merah mengalami keuntungan (dapat diteruskan)

Dimana:

$\mathrm{a}=$ Revenue Cost Ratio

$\mathrm{R}=$ Revenue / Penerimaan

$\mathrm{C}=$ Cost / Biaya

$\mathrm{P}=$ Output Price / Harga Produksi

$\mathrm{Q}=$ Output $/$ Jumlah Produksi

$\mathrm{FC}=$ Fixed Cost $/$ Biaya Tetap

$\mathrm{R} / \mathrm{C}$ menunjukkan berapa besarnya penerimaan yang diperoleh sebagai manfaat dari setiap rupiah yang dikeluarkan. Analisa $\mathrm{R} / \mathrm{C}$ dibedakan atas jenis biaya yang dikeluarkan, yaitu $\mathrm{R} / \mathrm{C}$ atas biaya tunai dan $\mathrm{R} / \mathrm{C}$ atas biaya total. Adapun kriteria keputusan dari nilai $\mathrm{R} / \mathrm{C}$ yaitu jika $\mathrm{R} / \mathrm{C}>1$, berarti penerimaan yang diperoleh lebih besar daripada tiap unit biaya yang dikeluarkan untuk memperoleh penerimaan tersebut. Jika nilai $\mathrm{R} / \mathrm{C}<1$ maka tiap unit yang dikeluarkan akan lebih besar daripada penerimaan yang diperoleh. Sedangkan kegiatan usaha yang memiliki nilai $\mathrm{R} / \mathrm{C}=1$ maka kegiatan usaha berada pada kondisi impas atau kondisi dimana kegiatan usaha tersebut tidak mendapatkan keuntungan dan tidak juga mengalami kerugian.

\section{HASIL DAN PEMBAHASAN}

\section{Deskripsi Daerah Penelitian}

\section{Letak Geografis dan Luas Wilayah}

Desa Tonsewer Selatan adalah sebuah desa yang terletak di wilayah kecamatan Tompaso Barat, Kabupaten Minahasa, Provinsi Sulawesi Utara yang terdiri dari empat jaga dengan batas wilayah:

Sebelah Utara : Desa Tonsewer

Sebelah Bara : Desa Touure Dua

Sebelah Selatan : Hutan lindung kalelondey

Sebelah Timur : Desa Pinabetengan Selatan

Ketinggian antara 500-750 meter diatas permukaan laut serta pengaruh gunung berapi yitu gunung soputan sangat menunjang kesuburan tanah dikawasan ini sehingga baik 
dipergunakan untuk mengusahakan berbagai komoditas pertanian termasuk didalamnya bawang merah.

Luas wilayah Desa Tonsewer Selatan adalah kurang lebih $125 \mathrm{Ha}$. Kecamatan ini berjarak 2,5 $\mathrm{km}$ dari pusat pemerintahan Kecamatan (Tompaso Barat), dan $28 \mathrm{Km}$ dari pusat pemerintahan Kabupaten (Minahasa), dan berjarak $51 \mathrm{~km}$ dari pusat pemerintahan Provinsi (Manado), dan jarak antara Kota Manado ke Desa Tonsewer Selatan di tempuh dengan kendaraan kurang lebih 2,5 jam iklim di Desa Tonsewer Selatan sama dengan iklim pada umumnya yakni beriklim tropis iklim sedang udaranya lembab, khas curah hujan yang cukup tinggi dan merata setiap tahun dan suhu maksimum $30^{\circ} \mathrm{C}$ dan suhu minimum sebesar $20^{\circ} \mathrm{C}$ Desa Tonsewer Selatan terbagi 4 dusun, jarak desa ke kecamatan 2,5 km.

Jumlah penduduk adalah 848 jiwa yang terdiri dari 488 laki - laki dan 416 perempuan sedangkan jumlah kepala keluarga sebanyak 266 KK. Pada umumnya masyarakat Desa Tonsewer Selatan beragama Kristen Protesan dan Kristen Khatholik.

\section{Jumlah Penduduk}

Jumlah penduduk di Desa Tonsewer Selatan memiliki jumlah penduduk 848 jiwa, yang tersebar dalam empat wilayah jaga. Hal ini dapat dilihat pada Tabel 2.

\begin{tabular}{|c|c|c|c|c|}
\hline \multirow[t]{2}{*}{ No } & \multirow[t]{2}{*}{ Jaga } & \multirow{2}{*}{$\begin{array}{c}\text { Jumlah } \\
\text { (KK) }\end{array}$} & \multicolumn{2}{|c|}{ Jumlah Jiwa } \\
\hline & & & Laki-Laki & Perempuan \\
\hline 1 & Jaga Satu & 71 & 104 & 107 \\
\hline 2 & Jaga Dua & 78 & 127 & 103 \\
\hline 3 & Jaga Tiga & 55 & 95 & 91 \\
\hline 4 & Jaga Empat & 62 & 121 & 100 \\
\hline & Total & 266 & 447 & 401 \\
\hline
\end{tabular}

Sumber: Data Sekunder Tonsewer Selatan, 2018

\section{Mata Pencaharian}

Tingkat perekonomian Desa Tonsewer Selatan umumnya ditentukan oleh sector pertanian. Sebagai mata pencarian adalah bertani yang berkisar 95 persen dan sisa 5 persennya adalah jenis pekerjaan lainnya sebagai peternak, pegawai negeri sipil, swasta dan pedagang. Tanaman hortikultura yang paling banyak ditanam oleh petani di Desa
Tonsewer Selatan yaitu bawang merah, hampir semua penduduk membudidayakan bawang merah lansuna.

\section{Karakteristik Responden Petani Tingkat Umur}

Mengenai usia produktif untuk bekerja yaitu mereka yang berusia antara 17 tahun sampai dengan 70 tahun. Cara berpikir dan kemampuan fisik petani sangat di pengaruhi oleh tingkat umur, secara fisik semakin tinggi umur petani maka semakin kurang kemampuan dalam bekerja, sedangkan petani yang berusia produktif pada umumnya mempunyai kemampuan fisik dan cara berpikir yang baik. Umur petani sangat mempengaruhi tingkat bekerja dan tenaga sehingga mempengaruhi pendapatan.

Tabel 3. Jumlah Umur Petani di Desa Tonsewer Selatan

\begin{tabular}{cccc}
\hline No & $\begin{array}{c}\text { Umur } \\
(\text { Tahun })\end{array}$ & $\begin{array}{c}\text { Jumlah } \\
\text { Responden }\end{array}$ & $\begin{array}{c}\text { Persentase } \\
(\%)\end{array}$ \\
\hline 1 & $27-36$ & 9 & 30 \\
2 & $37-46$ & 12 & 40 \\
3 & $47-56$ & 6 & 20 \\
4 & $>57$ & 3 & 10 \\
\hline & Total & 30 & 100 \\
\hline
\end{tabular}

Tabel 3 menunjukkan bahwa responden petani berumur produktif. Hal ini dilihat dari jumlah petani (responden) dengan usia 27-36 tahun sebanyak 9 (sembilan) orang (30\%), 3746 tahun sebanyak 12 (dua belas) orang (40\%) ,47-56 tahun sebanyak 6 (enam) orang 20\% dan interval lebih dari 57 tahun sebanyak 3 (tiga) orang (10\%). Pada umumnya petani responden berumur 37-46 tahun atau 40 persen dari keseluruhan petani responden bawang merah, kategori umur tersebut secara fisik tergolong masih kuat untuk bekerja mengelola usahatani.

\section{Tingkat Pendidikan}

Tingkat pendidikan seseorang akan mempengaruhi kreativitas dan kemampuan seseorang dalam menerima inovasi baru, serta berpengaruh terhadap perilaku petani dalam mengelola kegiatan usahataninya. Pendidikan adalah pembelajaran pengetahuan, keterampilan alat untuk mengembangkan diri, mental, pola pikir, dan kualitas diri seseorang. Makin tinggi pendidikan seorang petani maka makin tinggi 
pula tingkat petani dalam menjalankan tugas dan fungsinya dalam bekerja. Tingkat pendidikan akan mempengaruhi pengetahuan petani. Petani yang memiliki jenjang pendidikan tinggi pada umumnya akan lebih cepat menguasai dan menerapkan teknologi yang diterima dibandingkan dengan petani yang berpendidikan rendah. Tingkat pendidikan petani (responden) dapat dilihat pada Tabel 4.

Tabel 4. Tingkat Pendidikan Petani Responden di Desa

\begin{tabular}{cccc}
\multicolumn{4}{c}{ Tonsewer Selatan } \\
\hline No & $\begin{array}{c}\text { Tingkat } \\
\text { Pendidikan }\end{array}$ & $\begin{array}{c}\text { Jumlah Responden } \\
\text { (Orang) }\end{array}$ & $\begin{array}{c}\text { Persentase } \\
(\%)\end{array}$ \\
\hline 1 & S1 & 3 & 10 \\
2 & SMA & 6 & 20 \\
3 & SMP & 9 & 30 \\
4 & SD & 12 & 40 \\
\hline & Total & 30 & 100 \\
\hline
\end{tabular}

Tabel 4 menunjukan bahwa tingkat pendidikan petani tertinggi berada pada tingkat pendidikan S1 dengan jumlah petani responden 3 orang $(10 \%)$ sedangkan tingkat SMA dengan jumlah petani responden 6 orang (20\%), tingkat SMP dengan jumlah petani responden 9 orang (30\%) dan dengan jumlah latar belakang pendidikan yang rendah yaitu sebanyak 12 orang pada tingkat SD yaitu (40\%). Maka dapat dikatakan bahwa tingkat pendidikan petani bawang merah di Desa Tonsewer Selatan Kecamatan Tompaso Barat cukup relatif, karena sebagian besar petani responden pernah menempuh pendidikan meskipun berada pada tingkat yang berbeda.

\section{Pengalaman Berusahatani}

Tingkat pengalaman berusahatani yang dimiliki petani secara tidak langsung akan mempengaruhi pola pikir. Petani yang memiliki pengalaman berusahatani lebih lama akan lebih mampu merencanakan ushatani dengan lebih baik, karena sudah memahami segala aspek dalam berusahatani. Sehingga semakin lama pengalaman yang didapat memungkinkan produksi menjadi lebih tinggi. Pengalaman usahatani juga berpengaruh terhadap pengetahuan dan keterampilan petani dalam mengalokasikan produksi dalam penerapan suatu teknologi baru. Apabila pengalaman yang dimiliki petani semakin banyak maka akan dapat mendorong petani untuk menerapkan teknologi baru yang berguna untuk mendapatkan hasil yang lebih baik. Pengalaman petani dalam berusahatani bawang merah di Desa Tonsewer Selatan dapat dilihat pada Tabel 5.

Tabel 5. Pengalaman Berusahatani Petani Sampel di Desa Tonsewer Selatan

\begin{tabular}{cccc}
\hline No & $\begin{array}{c}\text { Pengalaman } \\
\text { Usahatani Bawang } \\
\text { Merah (Tahun) }\end{array}$ & $\begin{array}{c}\text { Jumlah } \\
\text { Responden }\end{array}$ & $\begin{array}{c}\text { Persentase } \\
(\%)\end{array}$ \\
\hline 1 & $6-16$ & 5 & 16,67 \\
2 & $17-27$ & 8 & 26,67 \\
3 & $28-38$ & 11 & 36,67 \\
4 & $>39$ & 6 & 20,00 \\
\hline & Total & 30 & 100 \\
\hline
\end{tabular}

Tabel 5 Menunjukan bawah pengalaman perberusahantai sangat penting yaitu kurang dari 6-16 tahun sebanyak 5 jiwa dengan persentase $16,67 \%$. Kemudian pengalaman bertani paling lama yaitu lebih dari 39 tahun sebanyak 6 orang dengan persentase $20 \%$. Sehingga dapat dikatakan bahwa pengalaman kerja petani bawang merah sudah cukup lama. Penduduk di Desa Tonsewer Selatan Kecamatan Tompaso Barat pada umumnya telah lama menjalankan usahatani bawang merah ini bahkan sudah sebagai mata pencarian yang turun temurun Berdasarkan hal tersebut petani memiliki perencanaan yang baik dalam mengelola usahatani bawang merah untuk kedepannya.

\section{Status Pemilikan Lahan}

Petani bawang merah di Desa Tonsewer Selatan ini kebanyakan memiliki status kepemilikan tanah sendiri atau lahan sendiri maka dari itu semua petani bawang merah hanya membayar pajak setiap tahun tanpa harus membayar biaya cukup strategis atau letak tanah yang tidak strategis maka dari letak tanah yang menuntukan berapa setiap tahun petani harus membayar pajak.

\section{Luas Lahan}

Lahan pertanian merupakan penentu dari pengaruh komoditas pertanian. Secara umum dikatakan, semakin luas lahan (yang digarap/ditanami), semakin besar jumlah produksi yang dihasilkan oleh lahan tersebut. Ukuran lahan pertanian dapat dinyatakan dengan Ha. Petani masih menggunakan ukuran 
tradisional, misalnya patok dan jengkal Rahim, (2007). Lahan merupakan faktor produksi yang memegang peranan penting bagi setiap usahatani, karena lahan sangat dibutuhkan sebagai wadah untuk menanam komoditi atau tanaman yang ingin diusahakan oleh petani. Luas lahan untuk usahatani Bawang Merah di Desa Tonsewer.

Tabel 6. Luas lahan Petani di Desa Tonsewer Selatan

\begin{tabular}{cccc}
\hline No & $\begin{array}{c}\text { Luas lahan } \\
\text { Ha }\end{array}$ & $\begin{array}{c}\text { Jumlah } \\
\text { Responden }\end{array}$ & $\begin{array}{c}\text { Persentase } \\
(\%)\end{array}$ \\
\hline 1 & 0.5 & 9 & 30.00 \\
2 & 1 & 9 & 30.00 \\
3 & 1.5 & 7 & 23.33 \\
4 & 2 & 5 & 16.67 \\
\hline & Total & 30 & 100 \\
\hline
\end{tabular}

Tabel 6 Menunjukan bahwa jumlah petani yang mengelola lahan untuk usahatani bawang merah pada luas lahan 0,5 ha yaitu sebanyak 9 orang petani atau sekitar 30,00 persen, dan luas lahan 0,1 ha yaitu sebanyak 9 orang petani atau sekitar 30,00 persen, pada petani 1,5 ha yaitu sebanyak 7 orang petani atau sekitar 23,33 persen, sedangkan jumlah petani pada luas lahan 0,2 ha yaitu sebanyak 5 orang petani atau 16,67 persen dari total responden petani. Rata-rata penggunaan lahan pada usahatani bawang merah di Desa Tonsewer Selatan 0,1 ha sebanyak 9 petani bawang merah dengan persentase 30,00 persen.

\section{Modal Kerja}

Modal merupakan faktor yang paling penting dan sangat menentukan untuk dapat memulai dan mengembangkan suatu usaha. Modal dalam suatu usaha adalah seperti bahan bakar atau energy penggerak awal sebuah motor. Misalnya makin besar motor yang digerakkan maka makin banyak energy yang digunakannya dan akan semakin besar juga modal yang akan digunakan dalam usaha itu. Modal merupakan factor penentu dalam kegiatan produksi, besar kecilnya modal berpengaruh terhadap jumlah output yang dihasilkan. Jadi, apabila modal yang digunakan besar maka pendapatan yang diterima oleh petani bawang merah akan meningkat. Wijandi,
(2007). Untuk lebih jelas mengenai jumlah modal kerja usahatani bawang merah dapat dilihat pada Tabel 7.

Tabel 7. Modal Responden Berdasarkan Modal Kerja (1x Panen)

\begin{tabular}{|c|c|c|c|}
\hline No & $\begin{array}{c}\text { Modal Kerja } \\
\text { (Rp) }\end{array}$ & $\begin{array}{c}\text { Jumlah } \\
\text { Responden }\end{array}$ & $\begin{array}{c}\text { Persentase } \\
(\%)\end{array}$ \\
\hline 1 & $<29.000 .000$ & 9 & 30.00 \\
\hline 2 & $30.000 .000-35.000 .000$ & 9 & 30.00 \\
\hline 3 & $36.000 .000-40.000 .000$ & 12 & 40.00 \\
\hline & Total & 30 & 100 \\
\hline
\end{tabular}

Tabel 7 menunjukkan bahwa distribusi responden berdasarkan modal kerja yang digunakan oleh petani bawang merah dalam satu kali panen, dengan jumlah tertinggi yaitu dengan modal Rp.30.000.000 - Rp.35.000.000 sebanyak 9 petani dengan persentase $30,00 \%$ dan terendah yaitu petani menggunakan modal kerja < Rp.29.000.000 sebanyak 9 jiwa dengan persentase $30,00 \%$. Hal ini menunjukkan bahwa sebagian besar modal petani bawang merah menggunakan modal yang rata-rata tinggi sehingga tidak terlalu menghambat petani dalam bertani. Dan modal yang rendah sangat mempengaruhi pendapatan petani bawanang merah sehingga petani bawang merah sangat estra dalam memberikan pupuk dan pemberantasan hama agar tidak mendapatkan kerugian besar di karenakan modal yang rendah. Dalam kegiatan berproduksi modal yang paling mempengaruhi kegiatan bertani adalah tidak ada atau terbatasnya lahan yang dipakai untuk bertani bawang merah karena rata-rata masyarakat atau penduduk di Desa Tonsewer Selatan bertani dengan menggunakan lahan sendiri.

\section{Pajak}

Definisi pajak menurut Undang - undang Nomor 28 Tahun 2007 Pasal 1 Tentang Ketentuan Umum dan Tata Cara Perpajakan Pajak adalah kontribusi wajib kepada negara yang terutang oleh orang pribadi atau badan yang bersifat memaksa berdasarkan undangundang, dengan tidak mendapatkan imbalan secara langsung dan digunakan untuk keperluan negara bagi sebesar-besarnya kemakmuran rakyat. Definisi pajak yang dikemukakan oleh Rochmat Soemitro Mardiasmo, (2009) Pajak adalah iuran rakyat kepada kas negara berdasarkan Undang-Undang (yang dapat 
dipaksakan) dengan tidak mendapat jasa timbal balik (kontraprestasi) yang langsung dapat ditunjukkan, dan yang digunakan untuk membayar pengeluaran umum di Desa Tonsewer semua petani membayar sesuai harga yang di tawarkan dan letak tanah atau lahan, jika letak tanah petani bawang merah lebih strategis maka harga yang di bayar petani untuk pajak akan lebih tinggi di bandikan sama dengan letak tanah atau lahan petani yang tidak strategis maka harga nya akan lebih murah.

\section{Penggunaan Tenaga Kerja}

Tenaga kerja yang digunakan dalam usahatani bawang merah ada dua tenaga kerja yaitu tenaga kerja dalam keluarga dan tenaga kerja luar keluarga. tenaga kerja untuk jenis kegitan pengolahan lahan tanah, penanam, pemeliharan dan panen. Selanjutnya tenaga kerja untuk pengolahan lahan tanah meliputi bedengan dan persiapan tanah. Untuk tenaga kerja pemeliharan meliputi pemupukan, menyiang dan pemberantansan hama dan penyakit.

Tabel 8. Penggunan Tenaga kerja Pada Usahatani Bawang Merah Per Ha di Desa Tonsewer Selatan

\begin{tabular}{|c|c|c|c|c|}
\hline $\begin{array}{c}\text { Jenis } \\
\text { Kegiatan }\end{array}$ & Satuan & $\begin{array}{l}\text { Upah } \\
\text { (Rp) }\end{array}$ & $\begin{array}{c}\text { Jumlah } \\
\text { (HOK) }\end{array}$ & $\begin{array}{l}\text { Total } \\
\text { (Rp) }\end{array}$ \\
\hline $\begin{array}{l}\text { Pengelohan } \\
\text { Lahan }\end{array}$ & Hari & 120.000 & 7 & 840.000 \\
\hline Penanaman & Hari & 120.000 & 8 & 960.000 \\
\hline Pemeliharaan & Hari & 120.000 & 9 & 1.080 .000 \\
\hline Panen & Hari & 120.000 & 14 & 1.680 .000 \\
\hline Total & & & & 4.560 .000 \\
\hline
\end{tabular}

Tabel 8 Menunjukan bahwa rata - rata pengunaan tenaga yang banyak digunakan adalah tenaga kerja untuk panen dan penggunaan tenaga kerja yang sedikit adalah tenaga kerja pemeliharan dan tenaga kerja paling banyak dari tenaga kerja luar keluarga (TKLK). Tenaga kerja adalah penduduk dalam usia 1564 tahun yang dapat bekerja untuk memproduksi. Pengaruh tenaga kerja terhadap produksi tidak sama pada setiap cabang produksi (Daniel, 2002). Tenaga kerja merupakan faktor penting dalam usaha tani, khususnya tenaga kerja keluarga beserta anggota keluarganya.

Tenaga kerja merupakan faktor produksi yang penting dan perlu diperhitungkan dalam proses produksi dalam jumlah cukup bukan saja terlihat dari tersedianya tenaga kerja tetapi juga kualitas dan macam tenaga kerja perlu juga diperhatikan. Besar-kecilnya upah tenaga kerja ditentukan oleh mekanisme pasar, jenis kelamin, kualitas tenaga kerja dan umur tenaga kerja. Oleh karena itu, penilaian terhadap upah perlu di standarisasi menjadi hari kerja orang (HKO) Soekartawi, (2003).

\section{Peneriman Usahatani}

Kegitan usahatani bertujuan untuk mencapai produksi di bidang pertanian. nilai penjualan hasil (produksi) merupakan sumber penerimaan usahatani bawang merah adalah diperoleh dari perkalian antara jumlah produksi dan Harga jual. Dari 30 Petani responden bawang merah di Desa Tonsewer Selatan dengan Luas lahan 0,5 dengan rata - rata produksi sebesar $32.808 \mathrm{Kg}$ menghasilkan sebesar Rp.31.482.000 dan $1 \mathrm{Ha}$ rata-rata produksi $57.334 \mathrm{Kg}$ sebesar Rp.37.648.000 dan dengan luas lahan sebesar 1,5 Ha rata - rata produksi $60.729 \mathrm{Kg}$ sebesar Rp.40.039.000 dan petani Luas Lahan 2 Ha sebesar Rp.43.157.000 dan besar produksi sebesar $63.197 \mathrm{Kg}$. usahatani bawang merah berdasarkan luas lahan dan jumlah produksi yang di hasilkan dapat dilihat pada Tabel 9.

\begin{tabular}{|c|c|c|}
\hline Luas Lahan & $\begin{array}{l}\text { Produksi } \\
(\mathrm{kg})\end{array}$ & $\begin{array}{c}\text { Penerimaan } \\
\text { (Rp) }\end{array}$ \\
\hline 0,5 & 32.808 & 31.482 .000 \\
\hline 1 & 57.334 & 37.648 .000 \\
\hline 1,5 & 63.197 & 43.157 .000 \\
\hline 2 & 60.729 & 40.039 .000 \\
\hline
\end{tabular}

Tabel 9 Menunjukan bahwa petani bawang merah dengan luas lahan $0.5 \mathrm{Ha}$ menghasilkan penerimaan Terkecil Jika dilihat dari luas lahan yang lainnya dan luas lahan $2 \mathrm{Ha}$ jauh lebih besar mendapatkan penerimaan.

\section{Biaya Bibit}

\section{Biaya Variabel}

Bibit yang digunakan oleh petani sampel adalah bibit yang berasal dari petani sampel sendiri atau dibeli dari petani yang lain, Harga bibit tidak menentu karena ditentukan oleh jenis 
ukuran bibit dan harga bawang merah yang berlaku pada saat itu. Penggunaan bibit berdasarkan jumlah luas lahan dihitung per $\mathrm{Ha}$ dalam satu kali panen.

\section{Biaya Pupuk}

Jenis pupuk yang digunakan oleh petani sampel adalah pupuk Urea, Sp 36, Kcl, dan Npk. Pupuk Urea diberikan pada saat tanaman bawang merah berumur 1 minggu setalah masa tanam, kemudian pupuk susulan setelah umur tanaman mencapai 20 hari, 1 bulan sampai 40 hari dan dilanjutkan dengan memberikan pupuk Poska 10 hari sebelum masa panen. Biaya pupuk yang dikeluarkan dalam 1 kali panen.

\begin{tabular}{|c|c|c|c|c|c|c|c|}
\hline \multicolumn{8}{|c|}{$\begin{array}{l}\text { Tabel 10. Biaya Dan Jenis Pupuk Yang } \\
\text { Panen Dihitung Per Hektar }\end{array}$} \\
\hline \multirow{2}{*}{$\begin{array}{l}\text { Jenis } \\
\text { Pupuk }\end{array}$} & \multirow{2}{*}{$\begin{array}{c}\text { Harga } \\
\text { Pupuk } \\
\text { (Rp) }\end{array}$} & \multirow{2}{*}{$\begin{array}{l}\text { Luas } \\
\text { Lahan } \\
(\mathrm{Ha})\end{array}$} & \multicolumn{4}{|c|}{ Penggunaan Pupuk (kg) } & \multirow{2}{*}{ Total (Rp/Kg) } \\
\hline & & & Urea & Npk & Sp 36 & $\mathrm{Kcl}$ & \\
\hline Urea & 1.600 & 0.5 & 60 & $30 \mathrm{Kg}$ & $50 \mathrm{Kg}$ & $30 \mathrm{Kg}$ & 312.000 \\
\hline Npk & 1.800 & 1 & 100 & $50 \mathrm{Kg}$ & $50 \mathrm{Kg}$ & $50 \mathrm{Kg}$ & 440.000 \\
\hline Sp 36 & 2.400 & 1.5 & 200 & $150 \mathrm{Kg}$ & $100 \mathrm{Kg}$ & $150 \mathrm{Kg}$ & 870.000 \\
\hline $\mathrm{Kcl}$ & 1.400 & 2 & 250 & $200 \mathrm{Kg}$ & $150 \mathrm{Kg}$ & $200 \mathrm{Kg}$ & 1.400 .000 \\
\hline Total & & & $610 \mathrm{Kg}$ & $430 \mathrm{Kg}$ & $350 \mathrm{Kg}$ & $430 \mathrm{Kg}$ & 3.022 .000 \\
\hline
\end{tabular}

Tabel 10 menunjukkan bahwa biaya yang di keluarkan untuk semua jenis pupuk dalam 1 kali panen sebesar Rp.3.022.000. Biaya pengeluaran pupuk berdasarkan jumlah luas lahan.

\section{Biaya Pestisida}

Bahan - bahan pestisida ini dapat berupa zat kimia, mikrooganisme, maupun bahan tanaman lainnya. Pestisida bersifat menguntungkan bagi pertanian, tetapi bisa juga menimbulkan bahaya bila pengguna tidak benar hati-hati. Paham, (2012). Penggunaan pestisida ini sangat dibutuhkan untuk menjaga produksi tanaman dan juga untuk membasmi hama dan penyakit serta untuk memperbagus kualitas output. Penyemprotan pestisida dalam bertani bawang merah memiliki peranan yang sangat penting untuk itu petani bawang merah sangatlah rutin melakukan penyemprotan. Penyemprotan dilakukan setiap hari sebanyak dua kali dalam sehari sampai masa panen tiba. Jenis pestisida yang digunakan oleh petani bawang merah mempunyai harga yang bervariasi sesuai dengan merek dan kualitas.

\section{Biaya Produksi Bawang Merah}

Pada setiap kegiatan yang perlu diperhatikan adalah besarnya biaya yang dikeluarkan dalam satu kali proses produksi.

1. Biaya sarana produksi yaitu biaya untuk pembelian benih, pupuk, obat-obatan. Berdasarkan hasil penelitian petani bawang merah di Desa Tonsewer Selatan menggunakan benih lokal dengan harga yang berbeda-beda sedangkan untuk pemakaian pupuk yaitu pupuk Urea, Ponska, Kcl Sp 36 dibeli dengan harga yang berbeda-beda dan sedangkan pembelian obat pemberantas hama bervariasi menurut jenis dan merek pestisida.

2. Biaya tenaga kerja yang digunakan berasal dari dua sumber yaitu tenaga kerja dalam keluarga dan tenaga kerja luar keluarga diupah berdasarkan hasil kerja untuk pria dan wanita upah yang diterima bervariasi sesuai yang telah di tentukan.

3. Pajak tanah yang dimasukkan kedalam biaya produksi adalah pajak untuk satu kali panen. Besar pajak tergantung pada luas lahan dan letak posisi lahan tersebut.

Tabel 11. Per Hektar Usahatani Bawang Merah Pada Berbagai

\begin{tabular}{ccccc}
\multicolumn{4}{c}{ Luas Lahan untuk Satu Kali Masa Tanam } \\
\hline Bahan & Satuan & Jumlah & $\begin{array}{c}\text { Harga } \\
(\mathrm{Rp})\end{array}$ & Total \\
\hline Benih & $\mathrm{kg}$ & 163.306 & 15.000 & 2.449 .590 \\
Urea & $\mathrm{kg}$ & 1.220 & 1.600 & 1.952 .000 \\
$\mathrm{Sp} \mathrm{36}$ & $\mathrm{kg}$ & 700 & 2.400 & 1.680 .000 \\
$\mathrm{Kcl}$ & $\mathrm{kg}$ & 63,02 & 1.400 & 882,28 \\
$\mathrm{Npk}$ & $\mathrm{kg}$ & 700 & 1.800 & 1.260 .000 \\
Pestisida & $\mathrm{kg}$ & 3,50 & 60.000 & 560,00 \\
\hline Total & \multicolumn{4}{c}{} \\
\hline
\end{tabular}

Tabel 11 menunjukan jumlah pengeluaran biaya usahati bawang merah untuk pengelolaan Bawang Merah di daerah penelitian adalah Rp.8.783.590. Dimana semua jumlah dari pembelian bahan yang akan digunakan untuk pengelolaan Bawang Merah yang paling besar adalah pupuk urea sebesar Rp.1.952.000. karena dibutuhkan dalam jumlah banyak dan susahnya mendapatkan pupuk urea bersubsidi sehingga petani responden membeli pupuk non subsidi.

\section{Budidaya}

Usahatani bawang merah di Desa Tonsewer Selatan adalah salah satu usaha pertanian rakyat yang sudah lama dirintis dan telah membudaya dikalangan masyarakat. 
Hampir di setiap lahan pertanian baik itu lahan sawah maupun lahan kering, di tanami komoditas bawang merah.

Minat masyarakat sangat besar dalam mengembangkan usaha ini artinya perlu penanganan yang intensif, namun petani bawang merah di Desa Tonsewer Selatan dapat melakukan proses produksi usahatani bawang merah dua kali dalam setahun.

\section{Pengolahan Tanah}

Pengolahan tanah dilakukan untuk menghancurkan sisa -sisa tanaman, mengatur permukaan tanah, dan mengatur kelembabanya. Tanah diolah dengan bajak tradisional yang di tarik hewan atau dengan cangkul.

\section{Pembuatan bedengan}

Setelah permukaan tanah rata selanjutnya dibuat bedengan dengan lebar rata - rata 100 $\mathrm{cm}$ dan panjang bedengan disesuaikan dengan keadaan lahan sedangkan jarak tanaman rata rata adalah $20 \mathrm{~cm} \times 30 \mathrm{~cm}$. Penanaman bawang merah lebih baik menggunakan bedengan. Pembuatan bedengan disesuaikan dengan kebutuhan. Bedengan biasanya dibuat dengan ukuran 1,5 - 1,75 $\mathrm{m}$, diantara bedengan dibuat parit dengan ukuran $0,5 \mathrm{~m}$ dan kedalaman 0,5 dengan adanya bedengan ini dapat mengurangi resiko genangan air.

\section{Penanaman}

Setelah lahan telah siap untuk ditanami dan dan bibit bawang merah juga telah tersedia. Kemudian bibit bawang merah ditanam di tanah yang telah direndam dengan air $1-2$ sebelum waktu penanaman, tetapi sebelum melakukan penanaman tanah terlebih dahulu disemprot dengan pestisida khusus gulma supaya gulma tersebut tidak tumbuh lebih dulu sebelum tanaman bawang merah tumbuh, barulah dilakukan penanaman dengan jarak satu jengkal ibu jari dan jari telunjuk jarak antara sisi yang satu dengan sisi yang lain.

4. Pemumpukan

Petani bawang merah di Desa Tonsewer Selatan hanya sebagian petani yang memberikan pupuk kandang pada tanaman bawang merah. Untuk menambahkan unsur hara yang di perlukan tanaman petani hanya memberikan pupuk kimia seperti Urea, SP 36, $\mathrm{Kcl}$, Npk dan dari beberapa petani ada juga mengunakan Mutiara sebagai tambahan pupuk di bawang merah dan waktu pemupukan berbeda - beda untuk setiap petani namun pemberian pupuk diberikan dua kali bahkan sampai tiga kali.

5. Penyiangan

Untuk perawatan tanaman dilakukan penyiangan yaitu pembersihan rumput (gulma) yang menjadi pesaing utama tanaman bawang merah dalam memperoleh sinar matahari dan unsur - unsur tanah . Gulma pada lahan pertama dapat berkompetisi dengan tanaman dalam hal penggunaan air, unsure hara, cahaya matahari dan ruang hidup. Oleh karena itu dilakukan penyianagan. Penyiangan dilakukan dengan cara manual yaitu dengan mencabut atau di gali dengan menggunakan alat khusus untuk tanaman bawang merah atau bisa juga dengan menggunakan sabit apabila rumput atau gulmanya telah tumbuh besar. Pada saat penyiangan, petani biasa mencabut dan membuang tanaman bawang merah yang terkena penyakit atau hama. Pada penanaman bawang merah penyiangan biasanya dilakukan 1- 2 kali dalam satu kali panen.

6. Pemberantas Hama dan Penyakit

Serangan hama dan penyakit seringkali tidak dapat dihindarkan sehingga menyebabkan produksi menurun bahkan tidak jarang menggagalkan panen. Kegiatan pemberantasan hama dilakukan secara kimia seperti pestisida.

Salah satu masalah utama dalam bertani bawang merah adalah hama. Hama tanaman bawang merah yang banyak merugikan petani di Desa Sakuru. Daun bawang merah yang terserang hama ini akan dampak berbecak putuh memanjang, lalu kemudian layu, berlubang dan di dekat lubang tersebut terdapat kotoran ult. Pengendalian hama ini dapat dilakukan denga penyemprotan insektisida atau pestisida yang efektif.

7. Penyemprotan/Penyiraman dengan Air Paska Panen

Penyemprotan/penyiraman ini wajib dilakukan paska panen atau masa panen tiba. Fungsinya supaya biji bawang merah bertambah besar, daun dan batang bawang merah tidak cepat layu dan tua. Sehingga menghasilkan output yang berkelas dengan harga yang cukup tinggi. 


\section{Panen}

Bawang merah di panen pada umur 120 hari (4 bulan). Penen dilakukan dengan dicabut secara hati -hati setiap rumpun pohon bawang merah. umbi bawang merah di bersihkan dari kotoran yang menempel kemudian akarnya dipotong dengan pisau untuk mencegah agar umbi bawang merah tidak busuk dilakukan penjemuran yaitu sekitar 5-6 hari.

Pemanenan tanaman bawang merah biasanya tergantung dari bibit yang digunakan. Apabila bibit yang ditanam adalah bibit yang sudah lama disimpan biasanya tidak mencapai dua bulan dan apabila bibit yang digunakan bibit baru di panen dan langsung ditanam biasanya memakan waktu dua bulan lebih baru bisa di panen. Pemanenan dilakukan dengan cara menggali tanaman bawang merah dengan menggunakan alat khusus untuk memanen bawang merah.

Bawang merah yang telah digali akan di angkat dan dipindahkan oleh petani laiki-laki di satu tempat yang kering pemindahan ini dilakukan secara gotong royong oleh petanipetani bawang merah yang lain, kemudian bawang merah disimpan selama satu minggu dan ditutup dengan menggunakan terpal anti air yang besar supaya tidak dibasahi oleh air hujan maupun embun dan dibuka pada saat matahari terik agar bawang merahnya cepat kering. Pengeringan biasa dilakukan kurang lebih satu minggu, setelah satu minggu dikeringkan barulah bawang merah tersebut di ikat.

\section{Pendapatan Usahatani Bawang Merah}

Pendapat adalah jumlah penghasilan yang diterima oleh penduduk atas prestasi kerjanya selama satu periode tertentu, baik harianTujuan usahatani yang umum adalah untuk memperoleh pendapatan sebagai bagian dari upah mengisi kesejahteraan dan kepuasan secara maksimal. Petani dan keluarga yang menjalankan kegitan usahatani juga mempunyai tujuan yang demikian. Pendapatan yang diperoleh akan mendorong petani seperti untuk memenuhi kebutuhan hidup keluarga seharihari. Untuk lebih jelas mengenai pendapatan usahatani bawang merah dapat lihat pada Tabel 12.

\begin{tabular}{|c|c|c|c|}
\hline \multirow[b]{2}{*}{ Keterangan } & \multirow[b]{2}{*}{$\begin{array}{c}\text { Harga } \\
\text { Bawang } \\
\text { Merah } \\
(\mathrm{Rp} / \mathrm{Kg})\end{array}$} & \multirow[b]{2}{*}{$\begin{array}{c}\text { Jumlah } \\
(\mathrm{Kg})\end{array}$} & \multirow[b]{2}{*}{ Total (Rp) } \\
\hline & & & \\
\hline \multicolumn{4}{|l|}{ Penerimaan Usahatani } \\
\hline Bawang Merah Besar & 40.000 & 498.567 & 19.924 .680 \\
\hline Bawang Merah Kecil & 36.000 & 300.885 & 10.831 .860 \\
\hline Total Penerimaan & & & 30.756 .540 \\
\hline \multicolumn{4}{|l|}{ Biaya Tetap } \\
\hline Biaya Penyusutan alat & & & 1.984 .000 \\
\hline Biaya Pajak Tanah & & & 2.343 .042 \\
\hline Total Biaya Tetap & & & 4.327 .042 \\
\hline \multicolumn{4}{|l|}{ Biaya Variabel } \\
\hline Biaya Tenaga Kerja & & & 3.240 .000 \\
\hline Biaya Pupuk & & & 5.774 .000 \\
\hline Biaya Obat - obatan & & & 560.000 \\
\hline Biaya Bibit & & & $2.449,000$ \\
\hline Sewa Alat & & & 987,000 \\
\hline Total Biaya Variabel & & & 13.010.000 \\
\hline Total Biaya & & & 17.337.632 \\
\hline Total Penerimaan & & & 30.756 .540 \\
\hline Pendapatan Bersih/Keuntungan & & & 13.418 .908 \\
\hline $\mathrm{R} / \mathrm{C}$ & & & 1,77 \\
\hline
\end{tabular}

Tabel 12 menunjukan bahwa pendapatan rata - rata dengan keseluruhan Luas lahan yaitu sebesar Rp.13.418.908. Total biaya yang dibutuhkan dalam usahatani Bawang Merah di Desa Tonsewer Selatan adalah sebesar Rp.17.337.632, Sedangkan Penerimaan Rp30.756.540. dan untung $\mathrm{R} / \mathrm{C}$ adalah sebesar 1,77 dari perhitungan penerimaan dibagi dengan total biaya. Artinya bahwa setiap Rp.1 biaya yang dikeluarkan maka akan mendapatkan Pendapatan bersih (keuntungan) sebesar Rp.13.418.908.

\section{Analisis Revenue Cost Ratio (R/C)}

Analisis peneriman dan biaya produksi $(\mathrm{R} / \mathrm{C})$ dilakukan untuk mengetahui tingkat keberhasilan usahatani di Desa Tonsewer Selatan dengan kriteria:

Jika R/C $<1 \longrightarrow$ Usahatani bawang merah tidak berhasil atau rugi.

Jika $\mathrm{R} / \mathrm{C}=1 \longrightarrow$ Usahatani bawang merah tidak mengalami keuntungan dan kerugian.

Jika R/C > $1 \longrightarrow$ Usahatani bawang merah berhasil atau untung.

Untuk mengetahui usahatani responden petani bawang merah di Desa Tonsewer Selatan memperoleh keuntungan, rugi atau impas maka digunakan analisis Return Cost Ratio (RCR) yaitu dengan membandingkan antara penerimaan selama satu periode tanam yaitu sebesar Rp.30.756.540.000 dengan biaya produksi selama satu periode tanam yaitu Rp.17.337.632.000. 
Besarnya $\mathrm{R} / \mathrm{C}$ ration bawang merah dapat dilihat pada Tabel 12 diatas. Nilai Revenue Cost Ratio (R/C). yang diperoleh pada usahatani responden petani Bawang Merah di Desa Tonsewer Selatan adalah 1,77 artinya bahwa setiap Rp.1,00 biaya yang dikeluarkan maka akan mendapatkan penerimaan sebesar Rp.1,77. Kriteria $\mathrm{R} / \mathrm{C}>1=$ maka usahatani Bawang Merah di Desa Tonsewer Selatan menguntungkan.

\section{KESIMPULAN DAN SARAN}

\section{Kesimpulan}

Masyarakat Desa Tonsewer Selatan mengandalkan bidang pertanian bawang merah di karena mempunyai prospek yang cerah dalam arti layak untuk diusahkan (menguntungkan) Hal ini dapat di tunjukkan dari nilai $\mathrm{R} / \mathrm{C}$ ratio rata rata 1,77 yang di terima petani dari luas lahan yang mereka miliki.

\section{Saran}

Di harapkan bagi petani untuk terus mengembangkan usahatani bawang merah karena hasil penelitian, usahatani bawang merah mempunyai potensi untuk terus dikembangkan dikarenakan memiliki tanah yang subur dan iklim yang baik

\section{DAFTAR PUSTAKA}

Anonim. 2017. Badan Pusat Statistika Luas lahan dan Produksi dan hasil perhekter Bawang Merah Manado.

Daniel, M. 2002. Pengantar Ekonomi Pertanian. Bumi Aksara. Jakarta.

Natawidjaja R. S. 2007. Pengembangan komoditas bernilai tinggi (high value commodity) untuk meningkatkan pendapatan petani. Di dalam: Suradisastra K, Yusdja Y, Hutabarat B, editor. Prosiding Seminar Nasional Dinamika Pembangunan Pertanian dan Pedesaan : Mencari Alternatif Arah pengembangan Ekonomi Rakyat. 2007 Desember 04; Bogor, Indonesia. Bogor (ID) : PSEKP. hlm 17-29 Indonesia. Bogor.

Soekartawi dan Soeharjo A. 1985. Ilmu Usahatani dan Penelitian untuk Pengembangan Petani Kecil. Dillon JL, Hardaker, penerjemah; UI-Press. Terjemahan dari: Farm Management Research for Small Development. Jakarta. 